Historic, Archive Document

Do not assume content reflects current scientific knowledge, policies, or practices. 
. 
62.27 .

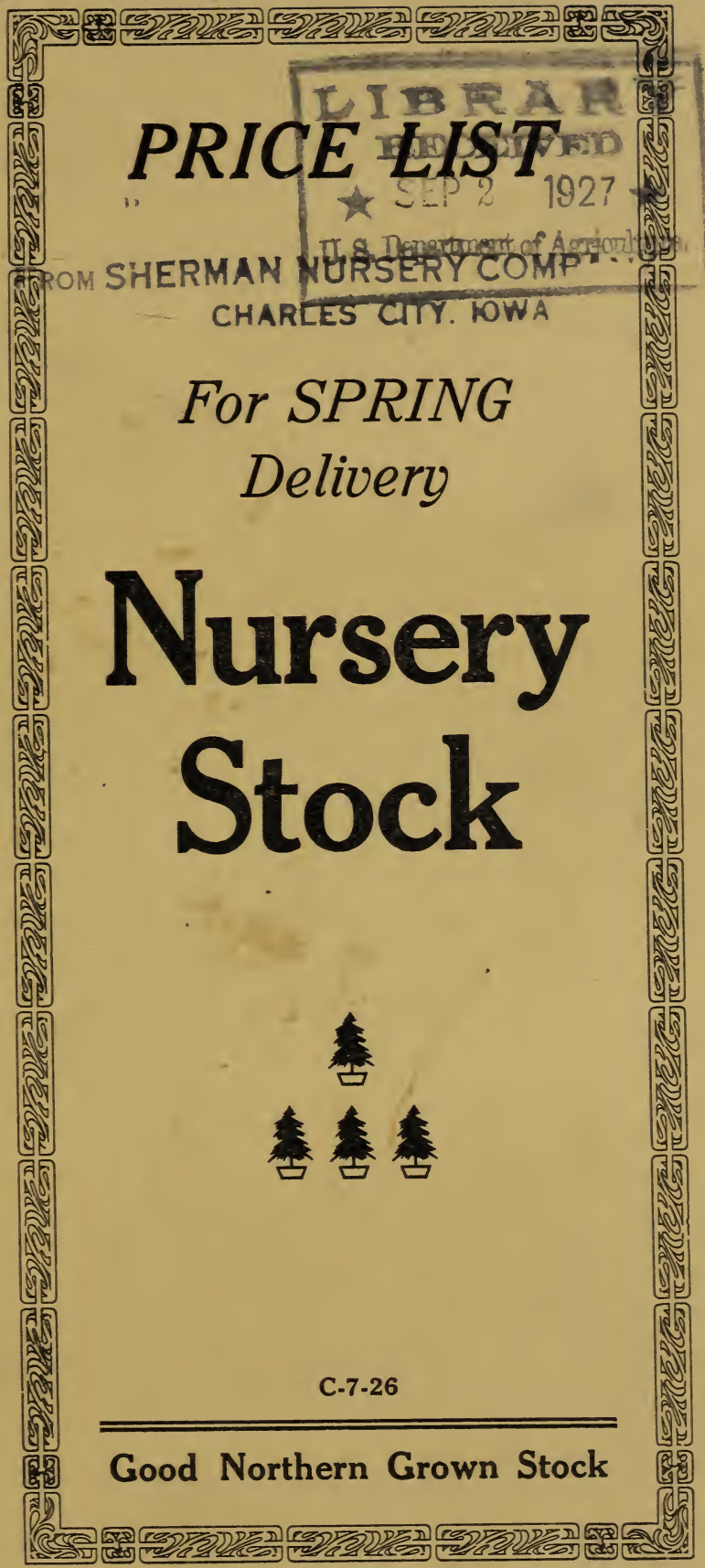




\section{Notes and Suggestions}

\section{Read Carefully}

1. Confine sales strictly to sizes and varieties in this list.

2. No order to be taken for less than $\$ 2.00$ worth of stock.

3. Take no order for delivery at places where there is no Railroad Station.

4. Take no order for delivery on a set date or during any certain month. Have order read Spring.

5. Use the utmost care in writing order, to have all figures, post office address, including rural route, and name written plainly, thus avoiding mistakes in filling orders.

6. Sign each order as Agent, have customer sign order where intended, write name of customer VERY PLAINLY at top of order.

7. Be sure that order is added up correctly and see that the amount of order, after deducting any credit for board or lodging, is carried to top of order and entered in blank space intended.

8. Size all stock where required to do so by order blanks, for instance, note space for size after Apples, Plums and Evergreens, be very careful to write sizes in order as they are listed in this price list, and do not under any circumstances write even size, as 5 feet, 6 feet, 18 inches; all such irregular sizes put us to lots of extra work, and we will return any order so sized.

9. See that delivery station is written in, also season of delivery, stating year, and ascertain correct postoffice address of customer.

10. Confine your sales to central delivery points. Avoid making deliveries at every little town; as a rule customers can be induced to go to your regular delivery station.

11. You may sell 500 at 1000 rates where thousand rate is given, 50 at 100 rate, except where otherwise noted. Sell Forest Trees in even hundreds only. In giving ten rates on Plum, Cherry, Grape Vines and transplanted Evergreens, we will not allow you to put in less than 2 of a variety in making up the ten, and in giving 100 rates, you must not put in less than 5 of a kind. On Currant, Gooseberry, Raspberry and Blackberry in giving ten rates, you must not put in less than 5 of a variety, and not less than 25 of a kind in giving 100 rates. 


\section{GENERAL INFORMATION}

\section{Replace Terms}

Any stock that fails to live, if given proper care, will be replaced FREE of charge (with exception of evergreens) providing we are notified before September 1st following delivery. Evergreens will be replaced at one-half price only.

\section{Delivery Season}

Never promise a customer a definite date for delivery. We guarantee to ship at the proper time for planting. Do not agree to deliver goods to premises, but instruct customers they will be notified to call at some centrally located place in town at delivery time. A delivery agent has plenty to attend to without making personal delivery of every package.

\section{We Pay Freight, Express or Parcel Post}

The prices quoted in this list are for goods delivered at any railroad station. Do not write up orders for delivery at inland towns (off the railroad). Some nurseries make an extra charge of $10 \%$ or more to cover cost of packing and transportation.

\section{Terms of Payment}

All orders are taken with the understanding that cash will be paid in full at the time of delivery, unless payment has been made in advance.

\section{Prices}

In every instance the price named is entirely in keeping with the high quality of our guaranteed stock. Inferior grades of stock may be bought for less, but poor stock is dear at any price and an experienced planter, will not buy it. It is not so much what the customer pays as it is what he gets for what he pays that determines his degree of satisfaction.

\section{Packing}

Every customer's order is BURLAPPED at a heavy expense to assure delivery of his order in first class condition. Large orders are boxed in a separate box with plenty of moist packing material. No extra charge is made for this feature of service.

\section{Landscape Service}

To give our customers better plantings we maintain a Landscape Department. Plans will be furnished our customers free of charge with orders amounting to $\$ 75.00$ and over. Feel free to consult our Architect at any time with regard to planting arrangements and designs. See catalogue, page 60 . 


\section{Apples and Crab Apples}

The following list of apples contains only the rery choicest, hardy and productive varieties for planting in the upper Mississippi Valley:

\section{Summer Varieties}

Duchess

Anisim

Hybernal

Longfield

McMahon

Okabena

Ben Davis

Delicious

Gano

Golden Russett

Grimes Golden

Jonathan

King David

Malinda

McIntosh Red

M. B. Twig

Newell's Winter

Yellow Transparent

\section{Fall Varieties}

Patten's Greening

Peter

Wealthy

Wolf River

Fameuse (Snow)

\section{Winter Varieties}

N. W. Greening

Roman Stem

Rome Beauty

Salome

Stayman's Winesap

Talman Sweet

University

Willow Twig

Winesap

York Imperial

\section{Crab Apples}

\section{Hyslop}

Minnesota

Soulard

Strawberry Crab

Sweet Russett

Transcendent

Virginia

Whitney

Yellow Siberian

Each Per 10 Per 100

First Class, $4-5 \mathrm{ft} \ldots \ldots . . . . . . . . . . . \$ 1.00 \quad \$ 9.00 \quad \$ 80.00$

Specimen, 5-6 ft.

1.2512 .00

\section{Recent Introductions}

Four best varieties originated by C. G. Patten.

Brilliant (Winter)

Silas Wilson (Winter)

SELECT TREES, 4-5

EXTRA FANCY, 5-6
Summer Pear (Summer)

Eastman (Fall)

$\mathrm{ft}$.

$\$ 1.50$ Each

2.00 Each

\section{Special-Five-in-one Apple}

This tree will produce five different kinds of apples, covering a period from early summer to late winter. The four best varieties originated by $\mathrm{Mr}$. C. G. Patten, Summer Pear, Eastman, Silas Wilson and Brilliant, are bud-grafted on University, an extra hardy and thrifty tree, making the fifth variety.

Select trees, 5-6 ft. $\$ 6.00$ Each 


\section{Pears}

Flemish Beauty

Keiffer

Bartlett

Above list, 4-5 $\mathrm{ft}$ $\$ 1.50$ Each Above list, 5-6 ft. (Specimen)

$2.00 \mathrm{Each}$

\section{Patten Pear}

A new pear originated at Charles City, Iowa. The only pear hardy for the Northwest, free from blight, a heavy bearer.

Introductory price, 5-6 ft......................\$5.00 Each

\section{Peaches}

Bokara Crawford's Early Elberta

First Class Trees, 4-5 ft..................\$1.00 $\$$ Each 10

Plums

$\begin{array}{lll}\text { Abundance } & \text { Monitor } & \text { Surprise } \\ \text { Burbank } & \text { Redwing } & \text { Wickson } \\ \text { Cheney } & \text { Underwood } & \text { Wolfe } \\ \text { DeSoto } & \text { Hawkeye } & \text { Wyant }\end{array}$

Forest Garden

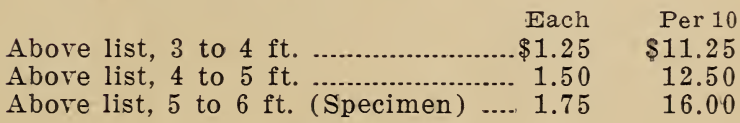

\section{New Plums}

Loring Prize Patten Plum Patten's XX

4 to $5 \mathrm{ft}$............................. \$2.00 Each

5 to $6 \mathrm{ft}$. (Specimen) ............. 3.00 Each, 2 for $\$ 5.00$

\section{Hansen's Plum Introductions}

$\begin{array}{llll}\text { Hanska } & \text { Kaga } & \text { Kahinta } & \text { Waneta } \\ \text { Sapa } & \text { Opata } & \text { Sansota }\end{array}$

Each Per 10

Above list, 3 to $4 \mathrm{ft}$.......................... \$1.25 $\$ 11.25$

Above list, 4 to $5 \mathrm{ft}$........................ $1.50 \quad 12.50$

Above list, 5 to $6 \mathrm{ft}$. (Specimen) .... $1.75 \quad 16.00$

\section{Zumbro and Compass Cherry}

\begin{tabular}{|c|c|}
\hline & \\
\hline$\ldots 1.25$ & $\$ 11.2$ \\
\hline $5 \mathrm{ft}$. & 12.5 \\
\hline $6 \mathrm{ft}$ (Specimen) & 16.0 \\
\hline
\end{tabular}

\section{Cherry}

Early Richmond Eng. Morello Ostheim

Mt. Morency Wragg Black Tartarian

Each Per 10

Above list, 3 to $4 \mathrm{ft}$........................ $\$ 1.00 \quad \$ 9.00$

Above list, 4 to $5 \mathrm{ft}$........................... $1.25 \quad 11.00$

Above list, 5 to $6 \mathrm{ft}$. (Specimen).... 1.50 13.00 


\section{Grapes}

\section{Strong Vines-Heavy Rooted}

Agawam

Pocklington

Brighton
Moore's Early

Niagara

Worden

Above list Each

Beta .65

Per 10

$\$ 5.00$

6.00

4.00

7.50

Alpha (new)

.50

1.00

Campbell's Early

1.00

7.50

Per 100

$\$ 40.00$

20.00

\section{Currants}

Strong Two Year, Ready to Bear

London Market

Victoria

Long Bunch Holland

Red Dutch

White Grape

Pomona

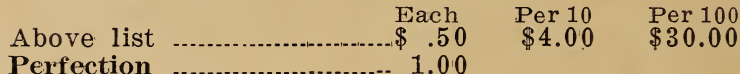

\section{Gooseberries}

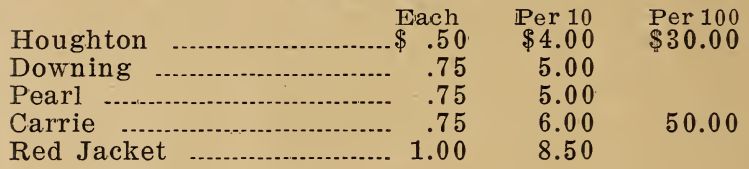

Red Raspberries

King Sunbeam St. Regis (Everbearing)

Above list ........................ $\$ 2.00 \quad \begin{array}{lrr}\text { Per } 100 & \text { Per } 1000 \\ \$ 15.00 & \$ 80.00\end{array}$

\section{Special New Red Raspberry "Latham"}

A valuaible recent introduction from the Minnesota State Experiment Station. Large red berry and a very heavy bearer.

Special Price

Per 10

Per 100

$\$ 20.00$

Per 1000 $\$ 3.00$

$\$ 100.00$

\section{Raspberries, 2 Year Transplants}

Cumberland (Black)

Gregg (Black)

Columbian (Purple)

Kansas (Black)

Above list

Patten's (Black)

Cardinal (Purple)

Redpath (Red)

Per 10 Per 100 $\$ 3.00 \quad \$ 20.00$

Every land owner, whether farm or city lot, should have a few currants and gooseberries, especially currants. Fine for jellies, preserves and for canning. Sure croppers. Very profitable on the local market, too. Every customer has a shady place in the garden or a bare fence line. These are ideal places for currants and gooseberries. See catalogue, page 18. 


\title{
Strawberries
}

Everbearing

Per 25

Per 100

Dunlap

$\$ 2.00$

$\$ 6.00$

1.00

3.00

We have experimented with nearly all the leading varieties of Strawberries and have come to the conclusion that all things considered, for general planting the Dunlap leads the list of June bearing varieties. It needs no fertilizer, is a large berry of a dark color, and bears an enormous crop. It is one of the best of shipping sorts

Our plants are packed in packages of uniform size, 25 to a bundle, and sales must be made in such a way as to permit the filling of orders without breaking bundles.

\section{Special New Everbearing}

\begin{abstract}
Per 25 Per 100
Number 999 Giant Everbearing

$\$ 3.00 \ldots \$ 10.00$

999 Giants are beautifully colored bright red berries, very large, often measuring up to $5 \frac{1}{2}$ inches around. Its flavor and fragrance are different from any other strawberry you ever tasted.
\end{abstract}

\section{Blackberries}

Two Years Strong (transplanted plants)

\begin{tabular}{|c|c|c|}
\hline & Per 10 & $\operatorname{Per} 100$ \\
\hline Ancient Britton & $\ldots 2.00$ & $\$ 15.00$ \\
\hline yder &.$\quad 2.00$ & 15.00 \\
\hline Rathburn & .. 2.00 & 15.00 \\
\hline
\end{tabular}

\section{Dewberry (Trailing Blackberry)}

\section{(Two years strong)}

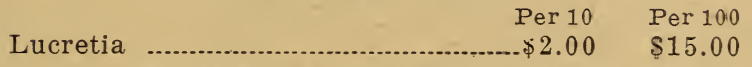

Cheap Blackberries and Dewberries are simply sprouts pulled up in old fruiting patches and are seldom a success. Our plants have been grown from root cuttings, have bushy, fibrous roots. They will succeed.

\section{Miscellaneous Fruits}

$\begin{array}{lrrr} & \text { Each } & \text { Per } 10 & \text { Per } 100 \\ \text { Dewberry, Lucretia } & \ldots . . . . . . . . . & \$ 2.00 & \$ 15.00 \\ \text { Dwarf Juneberry } & 5.00 & 50.00 \\ \text { Lucretia Dewberry .............. } & 2.00 & 15.00 \\ \text { Mulberry, Russ., } 12-18 \text { in. (bdls. of } 100 \text { ) } & 10.00 \\ \text { Mulberry, Russ, 2-3 ft. .... } & 3.00 & 25.00 \\ \text { Mulberry, Russ., } 5-6 \text { ft. .... } 1.00 & 8.50 & 75.00\end{array}$

\section{Vegetables}

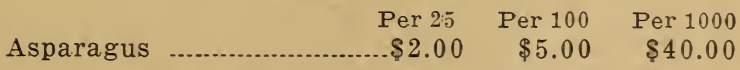

(Do not sell in lots less than 25)

No Spring Vegetable more welcome than Asparagus. It is easily grown and should be cultivated in every garden.

Horseradish 


\section{Weeping Trees}

Do not sell Cut Leaf Birch under any circumstances.

Each

Patten's Weeping Elm

Weeping Mt. Ash ……................................. 5.00

Niobe Weeping Willow (Golden) 6 to $8 \mathrm{ft}$....... 2.00

Tea's Weeping Mulberry ............................... 6.00

Wier's Cut Leaf Maple, 6 to $8 \mathrm{ft}$..................... 3.00

Catalpa Bungeii (Umbrella) ............................ 5.00

\section{Windbreak Evergreens}

Transplanted stock with bushy tops and plenty of fine fibrous roots.

Per $10 \quad$ Per 100

Arbor Vitae, 12-15 in. (Light) ...... $\$ 35.00$

Arbor Vitae, 12-18 in. (Heavy) ......\$ $6.00 \quad 50.00$

Arbor Vitae, 18-24 in. (Heavy) ...... $7.50 \quad 65.00$

Black Hills Spruce, 12-15 in............ 50.00

White Spruce, $12-18$ in. ............... $10.00 \quad 80.00$

White Spruce, 18-24 in. ................ 12.50 100.00

Per $100 \quad$ Per 1000

Jack Pine, Sdlgs., 6-10 in.............. 10.00 75.00

Ponderosa Pine, Sdlgs., 6-10 in. .... $10.00 \quad 75.00$

\section{Norway Spruce-Scotch Pine}

$\begin{array}{rrrr} & \text { Per } 100 & \text { Per } 200 & \text { Per } 500 \\ 15-18 \text { inch ....................... } \$ 30.00 & \$ 50.00 & 75.00 & \$ 125.00 \\ 18-21 \text { inch } & 450.00\end{array}$

\section{Evergreen “1215” (Special)}

Light transplanted trees, branched and well rooted, tied in bundles of 50 . Do not sell less than 50 of a variety.

Norway Spruce

Per 100

$\$ 20.00$

Per 200

$\$ 35.00$
Scotch Pine

Per $50^{\circ} \quad$ Per 1000

$\$ 80.00 \quad \$ 150.00$

These (Special) trees are 12 to 15 inches in height. Evergreens sold in lots of 100 or more will be packed in box by themselves, but under no circumstances sell less than 50 of a variety. Evergreen " 1215 " is the ideal grade to be used for shelter belt planting and sales should be encouraged in 1000 lots.

\section{Small Windbreak Evergreens}

Transplanted trees, 6-10 inches in height, grown in the open field, hardy and well rooted. Sell in lots of 50 or more. Varieties listed below especially good in Western Iowa, Minnesota, Dakotas and the Northwest.

White Spruce

Special Price
Black Hills Spruce 


\section{Specimen Evergreens}

The trees listed below have been grown in $w$ ide rows with plenty of room to develop a symmetrical, shapely and heavily branched tree. They have been root pruned, and are extra well rooted.

Each tree in this specimen class sold at the following prices will be balled in moss, which will insure excellent results in planting. Customer may have them balled in earth and burlapped for an additional charge of $\$ 2.50$ per tree, if each item is marked "B \& B"'.

Arbor Vitae, Globosa, Bushy Specimens, top

18 in. diameter .......................................... \$

Arbor Vitae, Pyramid, 2-3 ft.

$\mathrm{Each}$

Arbor Vitae, Pyramid, 18-24 in. .....................

Arbor Vitae, Siberian, 2-3 ft. ........................

Austrian Pine, 12-18 in.

Austrian Pine, 18-24 in.

Austrian Pine, 2-3 ft.

7.50

5.00

5.00

2.00

3.00

Black Hills Spruce, 18-24 in. ...................... 3.00

Black Hills Spruce, 2-3 ft. ........................... 4.00

Black Hills Spruce, 3-4 ft. .......................... 5.00

Colo. Green Spruce, $18-24$ in. ....................... 3.00

Colo. Green Spruce, 2-3 ft. ....................... 4.00

Colo. Blue Spruce, Select Blue, 18-24 in. ...... 10.00

Colo. Blue Spruce, Select Blue, 2-3 ft. ......... 15.00

Douglas Spruce, 2-3 ft. ................................. 4.00

Douglas Golden Arbor Vitae, 12-18 in. ......... 4.00

Juniper, Pfitzeriana, 18 in. diameter ........... 5.00

Juniper, Pfitzeriana, 24 in. diameter ............ 7.50

Juniper, Savin, 24 in. diameter .................... 5.00

Juniper, Savin, 30 in. diameter ..................... 7.50

Irish Juniper, 2-3 ft. .................................... 5.00

Mugho Pine, 10-12 in. diameter .................... 5.00

Norway Spruce (Specimen), 4-5 ft. ............. 7.50

Ponderosa Pine, 18-24 in. .............................. 3.00

Swedish Juniper, 2-3 ft. .............................. 5.00

Juniper, Tamariscifolia, 18-24 in. .............. 6.00

\section{SPECIMEN EVERGREENS}

Evergreens not only help to cheer the winter months by the contrast of their brightly colored foliage with the snow, but their rarying forms of growth and colors of foliage add variety, attractiveness, to every planting.

They may be used in numberless ways and are used freely in plantings of distinction. Especially fine specimens of both the dwarf rarieties and large growing kinds are produced here in our Northern Nurseries. The use of our thrifty and hardy trees will insure success with sour evergreen planting.

The Arbor Vitaes and Junipers stand shearing well. The spruces may also be kept dwarf by cutting back the new growth each year.

The Black Hills Spruce is a popular, slow growing tree of great density and blue green foliage. It is absolutely hardy. It may be used in group plantings or as a single specimen. If pinched back in June it mas be kept dwarf. Very attractive in the spring when the buds open and the new growth starts.

You are invited to consult our landscape department as to choice of varieties and best methods of arranging and planting. 


\section{Shade and Ornamental Trees}

Ash, 6-8 ft.

Each

Box Elder, 6-8 ft.

$\$ 1.50$

Basswood (See Linden)

Black Walnut, 4-5 ft.

2.00

Black Walnut, 5-6 ft.

2.50

Boellena Poplar, 10-12 ft.

5.00

Butternut, 4-5 ft.

2.00

Butternut, 5-6 ft.

2.50

Bechtel's D. F. Crab

2.50

Carolina Poplar, Stocky Branched Trees, 5-6 ft.

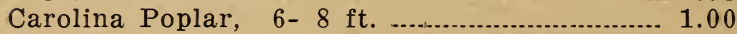

Carolina Poplar, 8-10 ft. ................................. 1.50

Carolina Poplar, 10-12 ft. ........................................

Catalpa Speciosa, 5-6 ft. ................................ 1.50

Catalpa Speciosa, 6-8 ft. '.................................... 2.00

Double Flowering Plum ................................... 2.50

Elm, Klehm's Moline Type, 6-8 ft. ............... 2.50

Elm, Klehm's Moline Type, 8-10 ft. ............... 3.50

Elm, Klehm's Moline Type, 10-12 ft. .............. 5.00

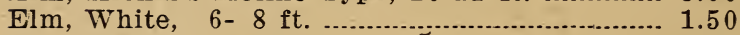

Elm, White, 8-10 ft. .................................... 2.50

Elm, White, 10-12 ft. .......................................... 3.00

Elm, White, $12-15 \mathrm{ft}$. $\left(1 \frac{1 / 4-11 / 2}{}\right.$ in. caliber $) \ldots . .5 .00$

Elm, White, $15 \mathrm{ft}$. and up ( 2 in. caliber) ........ 7.50

Golden Willow, 6-8 ft. ................................... 1.50

Hard Maple, 5- 6 ft. ...................................... 2.50

Hard Maple, 6- 8 ft. ......................................... 3.50

Hard Maple, 8-10 ft. ...................................... 5.00

Laurel Leaf Willow, 6-8 ft. ................................ 1.50

Linden (Basswood), 5- $6 \mathrm{ft}$............................ 2.00

Linden (Basswood), 6- 8 ft. ............................ 3.00

Linden (Basswood), 8-10 ft. ............................. 4.00

Maple, Soft (Same as Silver Maple. See next page.)

Lombardy Poplar, 5- 6 ft. ................................ 1.50

Lombardy Poplar, 6- 8 ft. ................................ 2.00

Lombardy Poplar, 8-10 ft. ............................... 2.50

Mt. Ash, European, 4-5 ft. ............................. 1.50

Mt. Ash, European, 5-6 ft. ............................. 2.00

Mt. Ash, European, 6-8 ft. ............................. 3.00

Mt. Ash, Oak Leaf, 4-5 ft. ........................... 2.50

\section{TRUE TO NAME}

In no nursery in the United States is there greater and more painstaking effort made to be absolutely sure that orders are filled with stock true to name. We grow our own trees 1000 acres of them. Every row of trees set out is staked as soon as planted and the trees are labeled as to the varieties. The size of the nursery and the scale upon which stock is grown is itself a guarantee to customers that they will get what they order. You cannot be sure of this when ordering from some small nursery where the assortment is limited. 


\section{Shade and Ornamental Trees (Cont.)}

Each

Norway Maple, 5- $6 \mathrm{ft}$. $\$ 3.00$

Norway Maple, 6- $8 \mathrm{ft}$.

Norway Maple, 8-10 ft. 7.50

Norway Poplar, Stocky Branched Trees, 5-6 ft.

Norway Poplar, $6-8 \mathrm{ft}$.

Norway Poplar, 8-10 ft.

Norway Poplar, 10-12 ft.

Schwedler's Purple Maple, 6-8 ft.

(Not branched)

Schwedler's Purple Maple, 8-10 ft. 8.00

(Not branched)

Silver Leaf Poplar, 5-6 ft.

Silver Leaf Poplar, 6-8 ft.

Silver Maple (Soft), 5- $6 \mathrm{ft}$.

Silver Maple (Soft), 6- $8 \mathrm{ft}$.

Silver Maple (Soft), o-10 ft.

Thorn Apple (Crataegus Punctata), 4-5 ft.... 5.00

Willow, Russian Golden, 6-8 ft. ........................ 1.50

Willow, Laurel Leaf; 6-8 ft.

Wier's Cut Leaf Maple, 5-6 ft.

Wier's Cut Leaf Maple, 6-8 ft.

3.00

\section{Nut Bearing Trees}

Black Walnut, 4-5 ft.

Each

Black Walnut, 5-6 ft. $\$ 2.00$

Hazel Nut, 3-4 ft.

Black Walnut, 1 yr., bundles of $100, \$ 10.00$ per 100

\section{LANDSCAPE SERVICE}

We maintain a Landseape Service Department for the assistance of our salesmen in selling larger orders and in giving better satisfaction to our customers.

The salesman's work is to properly interest his prospective customer in beautifying his property so that when a complete planting plan is drawn by our landscape department it can be sold without ans difficulty. These plans are expensive and require a lot of work to make them up. We urge that every salesman use his very best effort in selling the order after the plan has been drawn.

The salesmen who are making the most mones are those taking advantage of this landscape service. The following is a list of the prospective places for landscape work: Schools, Churches, Public Parks, Cemeteries, Oil stations, Private Residences, and new additions to towns and cities.

Write us at once if not entirely familiar with the way to proceed in order to get your share of the landscape business from your territory. 


\section{Forest Trees}

All except 2 to 3 and 3 to $4 \mathrm{ft}$ grades put up in bundles of 100 of a kind; 2 to 3 and 3 to 4 fit. grades put up in bundles of 50 . We do not break bundles.

Per 100 Per 1000

Ash, 6-12 in. $\$ 2.00 \$ \$ 10.00$

Ash, 12-18 in.

$3.00 \quad 20.00$

Ash, 18-24 in.

$4.00 \quad 30.00$

Ash, 2-3 ft.

$8.00 \quad 75.00$

Black Walnut, 1 year, 10-15 in. .. 10.00

Carolina Poplar, 12-24 in. ........... 4.00

30.00

Carolina Poplar, 2-3 ft.

$8.00 \quad 70.00$

Carolina Poplar, 3-4 ft.

$10.00 \quad 90.00$

Catalpa Speciosa, 18-24 in.

5.00

40.00

Norway Poplar, 12-24 in.

4.00

30.00

Norway Poplar, 2-3 ft.

$8.00 \quad 70.00$

Norway Poplar, 3-4 ft.

10.00

90.00

Russian Olive, 12-18 in.

125.00

White Elm, 6-12 in.

2.00

10.00

White Elm, 12-18 in.

$3.00 \quad 20.00$

Willow, Laurel Leaf, 12-24 in. ....

$5.00 \quad 40.00$

Willow, Laurel Leaf, 2-3 ft.

$7.00 \cdot 60.00$

Willow, Laurel Leaf, 3-4 ft.

90.00

Willow, Russian Golden, 12-24 in. $5.00 \quad 40.00$

Willow, Russian Golden, 2-3 ft. .- $7.00 \quad 60.00$

Willow, Russian Golden, 3-4 ft. .. $10.00 \quad 90.00$

Claremont, S. D.

Gentlemen: Replying to your inquiry as to my way of planting trees which resulted in the success I reported to you, will say that I plewed very deep, then disked several times to pack the soil, then harrowed a couple times to level the ground. All this was done early in the spring just after the frost was out of the ground. When the trees came, I opened the box and bundle as we needed them, puddled them in a tub of thin mud so that the roots of all the trees were all covered with mud. I then put them in the ground behind a spade and packed the ground well. Later I cultivated shallow every week until August when we had our first rains. After each cultivation, I went over each row with a hoe and made a fine dust mulch around each tree. I have never failed yet on trees, using the above method. Some of the Ash and EIms made a growth of three feet last season and the Poplar six to seven feet. I think I have as fine a grove started here as can be found anywhere. I am

Yours respectfully, HENRY SWANSON.

Ir. Swanson's order consisted of 2,000

Forest Trees and 600 Russian olive. 


\section{Hedging}

Put up in bundles of 25 of a kind. In lots of less than 25 sell at prices on following pages. Hedges listed in this group should be clipped for the best effect.

Per 100

Alpine Hedge, 12-18 in.

$\$ 40.00$

Alpine Hedge, 18-24 in.

50.00

Arbor Vitae, 12-15 in.

35.00

Arbor Vitae, 12-18 in.

50.00

Arbor Vitae, 18-24 in.

65.00

Box Barberry (Dwarf) 6-10 in., Bushy ........ 35.00

Buckthorn, 12-18 in. .................................. 15.00

Buckthorn, 18-24 in. ................................... 25.00

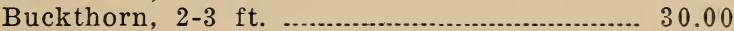

Caragana (Siberian Pea Tree), 12-18 in. .... 15.00

Caragana (Siberian Pea Tree), 18-24 in. .... 20.00

Caragana (Siberian Pea Tree), 2-3 ft. .......... 25.0 20

Eleagnus (Russian Olive), 12-18 in. ........... 15.00

Eleagnus (Russian Olive), 18-24 in. ............ 25.00

Purple Lilac, 18-24 in. .................................. 40.00

Tartarian Honeysuckle, 18-24 in. ................ 40.00

Thunbergii (Jap. Barberry), 12-18 in. ........ 25.00

Thunbergii (Jap. Barberry), 18-24 in. ....... 35.00

Salix Uralensis, 18-24 in. .............................. 25.00

\section{Unclipped Hedges}

Spirea Van Houteii (Bridal Wreath),

18-24 in.

Spirea Froebelli (Crimson Flower) 18-24-in. 50.00

Spirea Thunbergii (Early White) 18-24 in... 50.00

\section{Privet Hedges}

(Clipped)

Per 100 $\$ 20.00$

Amoor River Privet, 12-18 in. 25.00

Amoor River Privet, 18-24 in. 15.00

California Privet, 12-18 in.

20.00

California Privet, 18-24 in.

Note-Do not sell Privet north of Des Moines, Iowa. Not reliably hardy except in Missouri, Fansas and Central Illinois.

\section{AI.PINE HEDGE}

ALPINE HEDGE is growing in demand every year and bids fair to become the leading dwarf hedge where a sheared hedgeline is desired. It possesses certain elements of superiority which are naturally responsible for this fact. Perfectly hardy in all parts of the North in the most exposed locaticns.

It is also a true drought resister, and has been known to pull through the driest summers without watering, and maintain a bright, healthy foliage throughout the season. 


\section{Flowering Shrubs}

(Usually two to three feet, but dwarf sorts will run fifteen inches and up.)

Acer Ginnala, (Japan Maple), beautiful cut foliage. Bridal Wreath (Spirea Van Houttei)

Buffalo Berry

Cornus (Red Branched Dogwood)

Cut Leaf Elder

Cut Leaf Golden Elder

Cornus, Paniculata

Euonymous

Forsythia

Lilac, Purple

Russian Olive

Snowberry, Red

Snowberry, White

Spirea Billardi

Spirea Callosa Alba, 12-18 in.

Spirea Crispifolia (Bright Pink)

Spirea Froebelli

Spirea Opulifolia

Spirea Van Houttei (Bridal Wreath)

Syringa Coronarius (Sweet Scented)

Syringa or Mock Orange

Syringa Grandiflora

Syringa Lemoinei

Tartarian Honeysuckle (White or Pink)

Japanese Barberry, 18-24 in.

Above List, 75c Each, \$70.00 Per 100

\section{Select Flowering Shrubs}

D. F. Althea

Butterfly Bush

Clematis Recta (Upright Bush Clematis)

Elder, Red Berried

High Bush Cranberry

Honeysuckle Morrowii

Kerria Japonica

May Day Tree

Snow Ball

Spirea A. Waterer

Spirea Bumalda
Spirea Callosa Rosea

Spirea Fortuneii

Spirea Sorbifolia

Spirea Superba

Spirea Thunbergii

Sumac, Smooth

Symphoricarpos Mollis

(New White Snowberry with extra large waxy white berries. Splendid for shade.)

Tamarix

Japanese Barberry, 2-3 ft.

Above List, \$1.00 Each, \$9.00 Per Ten, $\$ 85.00$ Per 100

\section{HOW TO SELL SHRUBS}

Where any quantity of shrubs or other ornamentals are needed by the customer SELL BY SKETCH. Make up a rough sketch of the place, outlining the beds or borders to be planted, AND THEX SELL ALL AS ONE UNIT, instead of attempting to sell one shrub or one variety at a time. If you cannot make sketches, write us, we will help you. Our heaviest salesmenthose making the biggest moner-are those who sell ornamentals by sketch or plan. 


\section{Choice Flowering Shrubs}

Aralia Spinosa (Hercules Club)

Cornus Elegantissima (Green and White Leaf)

Deutzia Lemoinei

Deutzia, Pride of Rochester

Flowering Almond

Golden Elder

Honeysuckle, Ruprechtiana

Hydrangea, Arborescens Sterilis

Hydrangea, P. G.

Japan Quince

Lilac, Villosa

Lilac, Josikea

Lilac, Persian White

Lilac, Persian Purple

Lilac, White

Purple Fringe (Smoke Tree)

Snowball (Japanese)

Spirea Arguta

Spirea Aurea (Golden)

Spirea Callosa Rubra

Sumac, Cut Leaf

Sumac, Staghorn

Syringa, Golden

Syringa Virginalis (Double)

Viburnum Dentatum (Arrow-Wood)

Viburnum Lentago (Black-haw)

Viburnum Tomentosum Plicatum

Viburnum Lantana

Weigelia Rosea

Weigelia Eva Rathke

Weigelia, Variegated

Above List, \$1.50 Each, \$12.50 Per Ten.

\section{Special Flowering Shrubs}

Double Flowering Plum $\$ 2.50$

Bechtel's D. F. Crab

Hydrangea, P. G. Tree Form

2.50

Prunus Pissardi (Purple Leaf Plum)

Hansen's Purple Plum 


\section{Fancy Lilacs}

Charles $\mathrm{X}$

Michel Buchner

Chinensis Alba

Chinese Tree Lilac

Japanese Tree Lilac

Ludwig Spaeth
Marie Legraye

Mme. Lemoine

Mme. Casimir Perier

President Grevy

Rothomagensis

$\$ 2.00$ Each, \$17.50 Per 10

\section{Roses}

Our Roses are strong two-year plants, grown outdoors, well rooted, in every way first class, and with but few exceptions are on their own roots. They will bloom the same season they are set out, and are in every respect much better and stronger plants than the ones that are so freely advertised and sent out by mail, and which are small, tender shoots started in a greenhouse, and sent out before they have established growth and constitution enough to stand the shock of transplanting. In planting, cut branches back to within six inches of the main stem.

American Pillar Baltimore Belle Crimson Rambler Dorothy Perkins

(Pink Rambler)

\section{Climbing Roses}

Excelsa (Red)
Paul's Climber (Pink)
Prairie Queen
Seven Sisters

Above List, \$1.25 Each

\section{Special Climbing Roses}

Flower of Fairfield (Everblooming Crimson Rambler), \$2.00 Each.

\section{F. J. Grootendorst Rose}

We are introducing a new rose this season that will please your customers. It is a cross between the Japanese Rose (Rosa Rugosa) and the everblooming Baby Rambler. The foliage is beautiful, the flowers crimson and fragrant. Should be severely pruned each season.

Price \$2.00 Each, 2 for: $\$ 3.00$

\section{Baby Rambler (Everblooming)}

Red, White, Pink $\$ 1.50$ Each

\section{Hardy Hybrid Perpetual Roses}

African Black

Coq Des Alps

Frau Karl Druschki

General Jacqueminot

John Hopper

Madame Plantier

Magna Charta

Marshall P. Wilder

Crested Moss
Pink Moss

Mdm. Chas. Wood

Mrs. Jno. Laing

Paul Neyron

Persian Yellow

Rosa Rugosa (Single, excellent for foliage)

Red Moss

White Moss

Above List, $\mathbf{\$ 1 . 5 0}$ Each 


\section{Rcsa Rugosa (Double)}

Conrad F. Meyer (Pink) Mme. George Bruant

Hansa (Red)

(White)

Sir Thos. Lipton (White)

$\$ 2.00$ Each, 2 for $\$ 3.00$

\section{Hybrid Tea Roses}

Hybrid Tea Roses are commonly called Monthly or Everblooming Roses. They will produce an abundance of large fragrant flowers during the entire summer. Should be carefully protected during the winter by mounding up dirt eight or ten inches and covering with straw or leaves. Do not uncorer too early in the spring. The following two-year-old plants are available for spring planting. (No orders accepted for roses of any kind for FALL delivery.)

Mrs. Aaron Ward (Beautiful Indian Yellow)

Minnetonka (Shell Pink, Abundant Bloomer)

Grus An Teplitz (Dark Crimson)

Ophelia (Salmon-rose)

Premier (Dark Pink, Very Double)

Radiance (Large Pink, Very Fragrant)

White Killarney (Pure White)

Abore List, \$1.50 Each

\section{Vines}

Ampelopsis Engelmanii Hall's Japan Honeysuckle Ampelopsis Quinquefolia Moon Seed Vine

Bittersweet Trump. Honeysuckle

Chinese Matrimony Vine (Scarlet)

Chinese Yellow

Honeysuckle

Virginia Creeper, or American Ivy

Clematis Paniculata Wisteria Purple

Above List, \$1.00 Each; 3 of a Kind for \$2.50

\section{Special Vines}

Ampelopsis Veitchii (Jap. Creeper) (Boston Iry)

Aristolochio Sipho (Dutchman's Pipe)

Trumpet Vine (Bignonia Radicans)

Clematis Coccinea

Clematis Jackmanii (Purple)

Clematis Madam Edward Andre (Red)

Clematis Henryii (Large White) 


\section{Hardy Perennial Phlox}

This class of Hardy Perennials is of special importance in every flower garden. Succeeds in almost any soil and blooms through a long season. Our list covers a range of colors which is certain to please.

The best effects to be had with Phlox are produced by planting masses of each color, not less than six and even as many as two dozen or more plants of one color together. For example, a border of phlox may be planted, beginning with palest pink and shading up to dark cherry, then pure white and white with a red eye, and more white, then a quantity of red and again white at the end. If in another border the shades of purple are planted with occasional bunches of white, the Phlox will be the pride of the garden.

Mixed Colors, 25c Each, \$2.00 Per 10, \$17.50 Per 100

\section{Phlox (Named Varieties)}

Champs Elysees, Bright rosy-magenta.

Eclaireur, Bright rosy-carmine, with a light halo.

Eugene Danzanvillier, Lilac, shading white.

Mrs. Jenkins, Pure white.

Prof. Virchow, Bright carmine, overlaid with orange-scarlet.

Rheinlander, Beautiful large, salmon pink, deep red eye.

Ryndstrom, deep pink, tall.

R. P. Struther's, Rosy-carmine with claret eye; very bright, tall.

H. O. Wijers, White with red center, very pretty.

Abore List, 50c Each; $\$ 3.00$ Per Ten;

$\$ 25.00$ Per 100.

\section{New Varieties Phlox}

Elizabeth Campbell, Bright brilliant pink.

Double $\mathbf{X}$, Pinkish lavender with white eye.

Seibold, Bright orange-scarlet with crimson eye. Jules Sandau, Dwarfish. Large flower, pure pink.

Hindenburg, Crimson red with darker eye.

Chas. H. Mayo, Very large, white.

Baron Von Heeckeren, Delicate Salmon Pink.

Above-Iist, 75̄ Each, \$5.00 Per Tell. 


\section{Special Peonies}

Large, strong clumps of the best named varieties. Each clump will be packed in box by itself.

Caroline Mather, bright rosy-red. When in Each full bloom has a purplish tint. Midseason.. $\$ 3.00$ Drop-White Peony, white with rose red center, dainty, very fragrant

Festiva Maxima Peony, creamy white with small center of crimson, sweet-scented...... 3.00

Francis Ortegat, very dark red, almost purple; large double compact flowers, sweet scented 3.00 Humei Peony, beautiful bright pink, shading to rose, very large, late, one of the best .... 3.00 LeMartin, deep rose-red; stamens forming collar of gold; double flowers

Louis Van Houttei, deep velvety crimson, flowers medium size, very fragrant

Duchess de Nemours, beautiful new white peony, flowers large and double, fragrant.. 3.00 Edulis Superba, very early, shell pink, Generally in blossom Decoration Day

\section{Divided Clumps}

(3 to 5 Eyes)

Same varieties as above but not packed in

box (see descriptions above) $\$ 1.00$ Each

\section{New Peonies}

Aralanche. White. Strong grower, profuse bloomer, fragrant.

Baroness Schroeder. White, fringed petals. Delicate odor.

Eugene Verdier. Pink. Rose type, early. Outer petals lilac white. Very erect, rather dwarf in habit.

Mme. Emily Lemoine. White. Semi-rose type, mid-season. A strong grower and free bloomer; rare and beautiful.

Monsieur Jules Elie. Pink. Glossy flesh pink shading to a deeper rose at the base, the entire bloom covered with a silvery sheen. Strong grower. Very fragrant.

Reine Hortense. Pink. Very large, compact. Color a uniform hydrangea pink minutely splashed on a white background, with the center prominently flecked with crimson.

\section{3 to 5 Eye Plants Only, $\$ 2.00$ Each}

\section{Tenufolio Early Peony}

Tenufolio, leaf very finely cut, stem of medium length, flower rich velvety crimson, very full, fragrant; earliest of them all, double, divided plants only ...............\$2.50 Each 


\section{Hardy Perennial Flowers}

The list a number of the favorite flowers that lose their tops by dying down in the winter, but whose roots are preserved from year to year, consequently when once planted, they are perpetual, coming back each season with an increase in size of plant and flowering capacity. Just think of it-flowers all summer, all colors, every year, without special care or transplanting. Include perenniels in every order. Get better acquainted with them. See catalogue, page 52 .

Sell the following list at 50e each, $\$ 4.00$ per ten (unless otherwise noted)

Achillea. White only. Splendid for cemeteries.

Aster's. Hardy. Purple, Pink, White, Blue.

Aquilegia (Columbine). Yellow (Chrysantha).

Red (Canadensis). White (Alba).

Auratum Lily. Gold Banded Lily of Japan. \$1.00 Ea. Baby's Breath. White. Valuable for cut flowers. Bleeding Heart (Spectabilis) Com. variety. \$1 Ea. Bleeding Heart (Everblooming) \$1.00 Each.

Canterbury Bell. Pink, Blue, Purple or White.

Canna Bulbs. Yellow or Red.

Coreopsis. Flowers yellow only.

Chrysanthemum. Hardy. White, pink or yellow. Corn Lily (Day) Corn color.

Daisy. (Shasta) Dwarf. White only.

Daisy. (Giant) White only.

Dahlias. Assorted colors.

Funkia Alba (White Day Lily) $75 c$ Each.

Funkia Blue (Day Lily) 75 c Each.

Forget-Me-Not. Small blue flowers.

Foxglove (Digitalis) Yellow.

Gaillardia. Orange-red margined with yellow.

Gladioli. Common Red. $\$ 1.00$ per ten.

Gladioli. Choice Mixed Colors. \$1.50 per ten.

Gladioli. Groff's Hybrids. \$1.50 per ten.

Golden Glow. Bright Yellow. Tall.

Hollyhocks. Assorted colors.

Iris. (German) Yellow, orange, pink, purple, white.

Iris. (Japanese) Purple, blue, lavender. \$1.00 Each.

Iris. (Siberian) Yellow, purple.

Larkspur. (Delphinum) Blue.

Lemon Lily. (Yellow)

Lily of the Valley. Pure white. 25c Each.

Lancifolium Album (White) $\mathbf{7 5 c}$ Each.

Lancifolium Rubrum Lily (White, rose tint'd) $\mathbf{7 5}$.

Mallows (Hibiscus) Pink, red or white.

Oriental Poppy. Orange-scarlet.

Peonies. Red, white or pink. $75 \mathrm{c} \mathrm{Each.}$

Phlox. Various colors. (See page 16.)

Platycodon. (Balloon Flower) Blue only.

Regal Lily. Wonderful new lily. 75c Each.

Spirea Filipendula. Fern leaved, white flowers. 75c.

Sweet Williams. Flowers various colors.

Tiger Lily. Large golden orange. Attractive.

Salvia (Azurea) Sky Blue. Grows four feet high. Statice (Sea Lavender or Mist Flower) Blue, dwarf. Viola (Horned Violet) Mixed. Blooms all summer.

Vinca (Trailing Myrtle) Blue, dwarf. Early:

Yucca Filamentosa (Spanish Bayonet) Evergreen foliage, white blossom. Very ornamental. 


\section{FALL SALES}

Do not sell anxthing but the following items for Fill, DEIIVER: Peonies, Iris, Phlox, and Oriental Poppies. Fefer to your price list for quotations. Sell Bulbs for Fall Delivery ONLY, at the following prices: Tupils, single, assorted ..................... 1.50 Per Doz. Tulips, double, assorted 2.00 Tulips, Darwin, assorted 2.00 Hyacinths ( $75 \mathrm{c}$ each) Narcissi ( $75 \mathrm{c}$ each)

\section{Blooming Seasons of Popular Shrubs}

Date of bloom; color of flowers and attractive berries. Also shade loving shrubs.

\section{BLOOMING IN APRIL}

$\div$ * Barberry

Flowering Almonds

Golden Bell (Forsythia)

Spirea Arguta

Lilacs

Flowering Plum

Spirea Thunbergii

Japan Quince

\section{BLOONING IN MAY}

${ }^{*}$ Honeysuckles

Mock Oranges

Rosa Rugosa

Spirea Van Houttei

$\div$ *Dogwoods

*Arrowwood (Vib. Dendatum)

*H. B. Cranberry

Snowball

\section{BLOOMING IN JUTE}

Weigelias

* Bush Honeysuckle

Mock Orange

* Rugosa Roses

$\div *$ Golden Elder

Tamarix

Deutzea

Euonymous

Rhodotypus Kerrioides

Spirea Aurea

Flowering Currant

\section{BLOOMING IN JULY}

VVeigelias

$\div$ Hydrangea, A. S.

$\div$ †Rugosa Roses

Spirea Froebelli

$\div$ Snowberry, White

$\div$ *Snowberry, Red

Althea

Spirea A. Waterer

BLOOMING IN AUGUST

$\dagger$ Hydrangea A. S.

* Rugosa Roses

Spirea Froebelli

$\div *$ Snowberry, White

Sumac

Spirea Billardi

Spirea Bumalda

Spirea Sorbifolia
Yellow

White and pink

Yellow

White

Purple, red and white

Pink

White

Scarlet

Pink, yellow, red and white

Thite

Red and White

White

White

IVhite

White

White

Pink and red

Pink, red, yellow and white

IVhite

Red and white

White

Purple

IVhite

Pink

White

White

Yellow and white

Pink and red

White

Red and white

Red

Blue

White

Purple, pink and white

Red

\section{White}

Red and white

Red

Blue

Various

Pink

Red

White

\section{BLOOMING IN SEPTEMBER AND OCTOBER}

\section{$\leftarrow$ Hydrangea P. G. \\ $\leftarrow$ Hydrangea $\mathrm{A}$. S. \\ * Rugosa Roses}

Spirea Froebelli
White

White

Red and white

Red

$\doteqdot$ Do well in shady places; good for spots where too shady for grass.

* Have fall or winter berries. 


\section{A FEW FACTS}

OF INTEREST TO SALESMEN

We are the largest growers of evergreen trees in America, having over 30 acres covered with seed beds.

Our frost-proof packing house is $150 \times 300$ feet, making our packing facilities the best to be found in the United states.

In connection with our work, we are now operating one of the largest Greenhouse Plants in the state, having over 85,000 feet of glass.

\section{Suitable Distances for Planting}

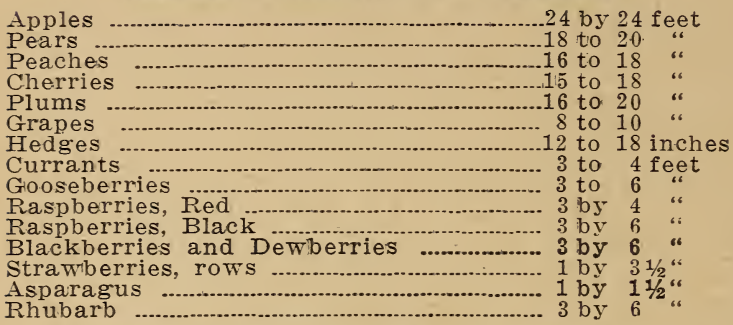

\section{Number of Trees or Plants on an Acre}

2 feet each way
3
4
4
5

To ascertain the number of plants required to the acre at any given distance, divide the number of square feet $(43.560)$ in an acre by the number of square feet you desire to devote to each plant. For inistance, in strawberries planted $1 \frac{1 / 2}{b y} 4$ feet each hill will occupy 6 square feet, making 7260 plants to the acre.

\section{Book Orders Early}

No nurseryman can carry a complete stock of everything ALL THROUGH THE ENTIRE SEAsoN. It is easier to sell a customer four months ahead of delivery date than to sell just before shipment. It costs the customer NoTHuNG to order early. Early orders receive complete protection on varieties and are always filled with best grades. Last year we had to turn down hundreds of orders for Apples, Evergreens, Hybrid Plums, Specimen Flowering Shrubs and other stock simply because the orders came too late. We were sold out. Book your orders early and avoid this loss and disappointment. 


\section{INDEX}

Apples and Crabs ......................................... 2

Blackberries ................................................. 5

Cherries ............................................................ 3

Currants ..................................................... 4

Dewberry ........................................................ 5

Evergreens ................................................ 6,7

Flowering Shrubs .................................. 12, 13

Forest Trees ............................................. 10

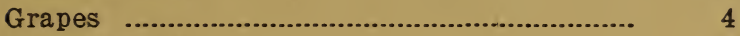

Gooseberries ................................................... 4

Hedge Plants ................................................... 11

Lilacs ............................................................ 14

Miscellaneous Fruits ..................................... 5

Nut Bearing Trees ......................................... 9

Peonies ......................................................... 17

Pears ................................................................ 3

Peaches ........................................................... 3

Perennials .................................................. 18

Phlox ............................................................. 16

Plums ............................................................... 3

Roses .......................................................... 14, 15

Raspberries .................................................. 4

Strawberries .................................................. 5

Shade and Ornamental Trees ......................... $\quad 8,9$

Vines ............................................................ 15

Vegetables ......................................................... 5

Weeping Trees ................................................ 6

GET US ANOTHER SALESMAN AND EARN $\$ 25.00$

Many of our best salesmen come to us through salesmen now in our employ.

For each salesman hired through jou, we will mail our check for $\$ 5.00$ when we have received from said agent $\$ 50.00$ in good orders. When the sales of the individual agent amount to $\$ 250.00$ we will mail you our check for \$10.00, and another check for $\$ 10.00$ will be mailed to you when we have received from said agent a total of $\$ 500.00$ in good business.

In sending names, remember that the only kind of people we are interested in are those who are strictly "on the square" and who are hustlers. We don't want the names of any men whose wishbones are where their backbones ought to be. 
